\title{
Methylation dynamics during folliculogenesis and early embryo development in sheep
}

\author{
Laura Masala, Giovanni Pietro Burrai, Emanuela Bellu, Federica Ariu, Luisa Bogliolo, \\ Sergio Ledda and Daniela Bebbere
}

Department of Veterinary Medicine, University of Sassari, Sassari, Italy

Correspondence should be addressed to D Bebbere; Email: dbebbere@uniss.it

\begin{abstract}
Genome-wide DNA methylation reprogramming occurs during mammalian gametogenesis and early embryogenesis. Post-fertilization demethylation of paternal and maternal genomes is considered to occur by an active and passive mechanism respectively, in most mammals but sheep; in this species no loss of methylation was observed in either pronucleus. Post-fertilization reprogramming relies on methylating and demethylating enzymes and co-factors that are stored during oocyte growth, concurrently with the re-methylation of the oocyte itself. The crucial remodelling of the oocyte epigenetic baggage often overlaps with potential interfering events such as exposure to assisted reproduction technologies or environmental changes. Here, we report a temporal analysis of methylation dynamics during folliculogenesis and early embryo development in sheep. We characterized global DNA methylation and hydroxymethylation by immunofluorescence and relatively quantified the expression of the enzymes and co-factors mainly responsible for their remodelling (DNA methyltransferases (DNMTs), ten-eleven translocation (TET) proteins and methyl-CpG-binding domain (MBD) proteins). Our results illustrate for the first time the patterns of hydroxymethylation during oocyte growth. We observed different patterns of methylation and hydroxymethylation between the two parental pronuclei, suggesting that male pronucleus undergoes active demethylation also in sheep. Finally, we describe gene-specific accumulation dynamics for methylating and demethylating enzymes during oocyte growth and observe patterns of expression associated with developmental competence in a differential model of oocyte potential. Our work contributes to the understanding of the methylation dynamics during folliculogenesis and early embryo development and improves the overall picture of early rearrangements that will originate the embryo epigenome. Reproduction (2017) 153 605-619
\end{abstract}

\section{Introduction}

DNA methylation at the 5-position of cytosine (5-mC) in mammals largely takes place in the context of CpGs and plays important roles in diverse processes including transcription regulation, maintenance of genomic integrity, regulation of genomic imprinting and X chromosome inactivation (Jaenisch \& Bird 2003). Despite the relative stability of DNA methylation in somatic cells, genome-wide DNA methylation reprogramming occurs twice during the life on an individual: in primordial germ cells and in preimplantation embryos (Reik 2007). The first extensive demethylation event occurs during gametogenesis, when the pre-existing epigenetic profile of the somatic cells is erased in primordial germ cells, while germ celland sex-specific epigenetic patterns are established during the later phases of gametogenesis (Smallwood \& Kelsey 2012). The second event of genome-wide epigenetic reprogramming occurs in the embryo soon after fertilization. Such remodelling is required for starting the new developmental programme of the nascent embryo.

The conventional model for epigenetic reprogramming postulates a parent-specific epigenetic reprogramming of the paternal and maternal genomes during the preimplantation development of most mammalian species. Up to recent times, the paternal genome was thought to be actively demethylated within a few hours after fertilization in the mouse, rat, pig, bovine and human zygote, whereas the maternal genome would be passively demethylated by a replication-dependent mechanism after the two-cell embryo stage (Mayer et al. 2000). Sheep was thought to escape from this model, as the loss of methylation from either pronucleus (PN) was not observed at any point in the first cell cycle in in vivoderived ovine zygotes (Beaujean et al. 2004). Recent studies partly defy this theory and suggest that parental pronuclei may share the major mechanisms of active and passive demethylation, which are differently modulated to achieve parent-specific patterns of methylation remodelling (Inoue \& Zhang 2011, Shen et al. 2014). 
Moreover, new dynamics that occur immediately after fertilization were evidenced, including a methylation maintenance during the $S$ phase in the paternal $P N$ of rabbit embryos after an early partial demethylation (Reis Silva et al. 2011). The new findings suggest that epigenetic reprogramming may be more complex than previously thought and call for further studies to revisit previous results.

DNA methylation status is largely determined by a balance between the actions of methylating and demethylating enzymes. DNA methylation is established and maintained by DNA methyltransferases (DNMTs) that catalyse the transfer of a methyl group from S-adenosylI-methionine to the fifth position of cytosine residues in DNA (Chen \& Li 2004). Two distinct mechanisms of DNA methylation activity exist: methylation maintenance and de novo methylation (Holliday \& Pugh 1975). The first is performed during DNA replication by Dnmt1, which accurately copies the methylation pattern of the existing DNA strand onto the new one (Bestor et al. 1988). De novo methylation process is mediated by Dnmt3a and Dnmt3b (Okano et al. 1998) that are extensively involved in re-methylation during oogenesis (Kaneda et al. 2004) and embryo development (Okano et al. 1999). Dnmt3L, despite the misnomer, is a catalytically inactive, related protein that modulates Dnm3a and Dnmt3b activity (Bourc'his et al. 2001). Conversely, DNA demethylation can take place either passively or actively. Passive demethylation occurs when DNA is replicated without re-methylation of the new DNA filament by DNMT1. The active mechanism, on the other hand, is a highly orchestrated enzymatic process involving ten-eleven translocation (TET) proteinmediated iterative oxidation (Ito et al. 2010, He et al. 2011) followed by thymine-DNA glycosylase (TDG)initiated base excision repair (He et al. 2011). Although all Tet family members (Tet1-3) possess 5-mC oxidation activity, they show cell- and tissue-specific expression patterns (Ito et al. 2010), suggesting different functional roles that are yet to be fully clarified. In accordance with the conventional model for epigenetic reprogramming, several studies have shown that Tet3 is involved in the active demethylation of the paternal genome (Inoue \& Zhang 2011, lqbal et al. 2011, Wossidlo et al. 2011); however, more recently Tet 3 was seen to contribute also to maternal DNA demethylation in zygotes, although to a lesser extent compared to that of paternal DNA (Shen et al. 2014).

The activity of methylating and demethylating enzymes is supported by several groups of proteins that act as co-factors and modulate and interpret DNA methylation patterns. These include the family of methyl-CpG-binding domain (MBD) proteins that play an important role in the regulation and interpretation of DNA methylation, chromatin-remodelling processes and gene expression. Currently, the MBD protein family consists of eleven known proteins containing an MBD domain that binds single symmetrically methylated CpG dinucleotides (Ohki et al. 2001); they are pivotal in linking methylation with transcriptional activity (Wade 2001) and act mainly as transcriptional repressors, but may also be involved in gene activation or expression modulation. The single members of the MBD family play cell- and developmental-specific roles, and may be involved in stem cell renewal, embryogenesis or differentiation (Hendrich et al. 2001). During embryogenesis, MBD proteins have been implicated in both global transcriptional regulation (Klose \& Bird 2006) and more specifically in the repression of Oct4, a pluripotency marker essential for early stages of mammalian embryogenesis (Gu et al. 2009). MBD1, 3 and 4 were also shown to be expressed in mouse and bovine oocytes (Ruddock-D'Cruz et al. 2008).

The molecules that support post-fertilization epigenetic reprogramming, including methylating and demethylating enzymes, are stored in the oocyte during its growth. The growing phase of the oocyte during folliculogenesis is therefore crucial for a proper definition of the epigenome in two ways: on one side, the molecules that will support epigenetic reprogramming during early development are accumulated; on the other side, the re-methylation of the oocyte itself with sex-specific epigenetic patterns occurs during the late stage of the growth. Despite the remodelling that erases most oocyte-specific methylation marks after fertilization, a memory of the epigenetic status of the gamete will be inherited by the nascent embryo, as in the case of imprinted genes (but not exclusively). The epigenetic baggage of the oocyte is therefore essential for its developmental potential; unfortunately, its remodelling often overlaps with potential interfering events such as exposure to assisted reproduction technologies (Young et al. 1998, Hansen et al. 2005) or environmental changes (i.e. nutrition, pathologies or accidental exposition to various contaminants) (Cortessis et al. 2012). Accurate knowledge of the methylation and hydroxymethylation status of the growing oocyte and on the molecules involved in their remodelling is fundamental to gain an overall picture of the early rearrangements that will originate the embryo epigenome.

Here, we analysed DNA methylation and hydroxymethylation during oocyte growth and maturation, in zygotes and early embryos in sheep. We illustrate for the first time hydroxymethylation during oocyte growth and we show different patterns of methylation and hydroxymethylation between the two parental pronuclei, suggesting that male $\mathrm{PN}$ undergoes active demethylation also in sheep. In parallel, we relatively quantified the expression of the enzymes mainly responsible for methylation remodelling, and linked the observed patterns with oocyte developmental competence using a differential model of gamete potential. 


\section{Materials and methods}

All chemicals in this study were purchased from Sigma Chemical unless otherwise stated.

\section{Oocyte recovery}

Oocytes were recovered from the ovaries of pre-pubertal (3040 days of age, body weight $6-10 \mathrm{~kg}$ ) and adult (4-5 years of age, body weight 35-40 kg) Sarda sheep, collected at a local slaughterhouse and transported to the laboratory within $1 \mathrm{~h}$ in Dulbecco's phosphate-buffered saline (PBS) with antibiotics. After washing in fresh medium, ovaries were sliced using a micro-blade and the follicle content was released in TCM-199 medium (with Earle's salts bicarbonate) supplemented with $25 \mathrm{mmol}$ HEPES, $0.1 \mathrm{~g} / \mathrm{L}$ penicillin, $0.1 \mathrm{~g} / \mathrm{L}$ streptomycin and $0.1 \%(\mathrm{w} / \mathrm{v})$ polyvinyl alcohol.

\section{Collection of growing oocytes}

Growing oocytes were selected from COCs derived from pre-pubertal donors, showing intact cumulus cell layers and a compact cytoplasm. After removal of cumulus cells by gentle pipetting with a fine bore glass pipette, oocytes were classified on the basis of their major diameter (average of two perpendicular measurements, excluding the zona pellucida) and grouped in three classes: oocytes with 70-90 $\mu \mathrm{m}$ (small;

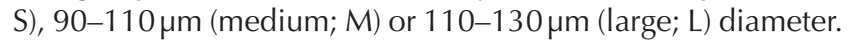

\section{In vitro maturation}

COCs derived from both pre-pubertal and adult donors, showing several intact cumulus cell layers and a compact cytoplasm, were selected and matured in vitro (IVM) in TCM 199 supplemented with $10 \%$ heat treated oestrus sheep serum (OSS), $10 \mu \mathrm{L} / \mathrm{mL} \mathrm{FSH/LH}$ and $100 \mu \mathrm{L}$ cysteamine. Then, 30-35 COCs were cultured for $24 \mathrm{~h}$ in $5 \% \mathrm{CO}_{2}$ in air at $38.5^{\circ} \mathrm{C}$ in four-well Petri dishes (Nunclon; Nalge Nunc, Roskilde, 100 Denmark) with $600 \mu \mathrm{L}$ maturation medium, layered with $300 \mu \mathrm{L}$ mineral oil. After IVM, oocytes underwent cumulus and corona cells removal by gently pipetting and only oocytes presenting compact cytoplasm and the first polar body were selected.

\section{In vitro fertilization and embryo development}

Frozen-thawed spermatozoa of one single ram of proven fertility (Sarda breed, 4 years old, body weight $55 \mathrm{~kg}$ ) were used for all in vitro embryo production experiments. Two straws were thawed per IVF and spermatozoa were selected by swim-up technique $\left(1 \times 10^{6}\right.$ spermatozoa $\left.* \mathrm{~mL}\right)$. IVM oocytes were incubated in synthetic oviductal fluid (SOF) medium (Tervit et al. 1972) with $2 \%$ OSS, $1 \mu \mathrm{g} / \mathrm{mL}$ heparin and $1 \mu \mathrm{g} /$ $\mathrm{mL}$ hypotaurine for $22 \mathrm{~h}$ at $38.5^{\circ} \mathrm{C}$ in an atmosphere of $5 \%$ $\mathrm{CO}_{2}$ and $5 \% \mathrm{O}_{2}$ in $\mathrm{N} 2$ in four-well Petri dishes (Nunclon, Nalge Nunc). Thereafter, presumptive zygotes were transferred and cultured for 8 days in four-well Petri dishes containing SOF plus essential and non-essential amino acids at oviductal concentrations (Walker et al. 1996) +0.4\% bovine serum albumin (BSA) under mineral oil, in a maximum humidified atmosphere with $5 \% \mathrm{CO}_{2}, 5 \% \mathrm{O}_{2}$ and $90 \% \mathrm{~N}_{2}$ at $38.5^{\circ} \mathrm{C}$ (Bogliolo et al. 2011). The first cleavage was recorded between 24 and $26 \mathrm{~h}$ after fertilization.

As a control for IVF procedure, a pool of embryos in each IVF run was cultured until the blastocyst stage to assess the developmental competence of the fertilized eggs. Only embryos collected from controlled experiments with rates of development to blastocyst stage at day $7>25 \%$ (pre-pubertal) and $>40 \%$ (adult) were used for the analysis.

\section{Gene expression analysis}

Details on gene expression analysis by real-time PCR are described according to the MIQE guidelines (Bustin et al. 2009).

\section{Sample collection for gene expression analysis}

The RNA samples were isolated from oocytes and embryos obtained during several IVM, IVF and IVC sessions, as given in the following:

- pools of denuded growing oocytes (GO) at different diameter (70/90, 90/110 and 110/130 $\mu \mathrm{m})$ derived from pre-pubertal (P) animals (5 pools of 30 oocytes per experimental group).

- Pools of denuded germinal vesicles (GV) and IVM metaphase II (MII) oocytes derived from $\mathrm{P}$ or adult (A) donors (5 pools of 10 oocytes per experimental group).

- In vitro produced (IVP) embryos at two- (2C) and four (4C)-cell stage derived from $\mathrm{P}$ or A donors (5 pools of 10 embryos per experimental group).

Oocytes and embryos were denuded via gentle pipetting in order to completely remove any somatic cell and added to $30 \mu \mathrm{L}$ RLT buffer (RNeasy Micro Kit, Qiagen), snap frozen in liquid nitrogen and stored at $-80^{\circ} \mathrm{C}$ until RNA isolation.

\section{$R N A$ isolation and reverse transcription}

Total RNA was isolated from the groups of oocytes and embryos with the RNeasy Micro Kit (Qiagen) following manufacturer's instructions. Five picogram of luciferase mRNA (Promega) were added to each group prior to RNA extraction to account for RNA loss during the isolation process. During the procedure, RNA was treated with DNase I to exclude any potential genomic DNA contamination. Isolated RNA was eluted in $12 \mu \mathrm{L}$ RNasefree water and immediately used for reverse transcription polymerase chain reaction (RT-PCR). Reverse transcription was performed in a final volume of $20 \mu \mathrm{L}$, consisting of $50 \mathrm{mM}$ Tris- $\mathrm{HCl}$ (pH 8.3), $75 \mathrm{mM} \mathrm{KCl}, 3 \mathrm{mM} \mathrm{MgCl} 2,5 \mathrm{mM}$ DTT, $1 \mathrm{mM}$ dNTPs, $2.5 \mu \mathrm{M}$ random hexamer primers, $0.05 \mu \mathrm{g}$ oligo $(\mathrm{dT})$, primers, $20 \mathrm{U}$ RNase OUT and $100 \mathrm{U}$ SuperScript III RT (all purchased at Invitrogen). The reaction tubes were incubated at $25^{\circ} \mathrm{C}$ for $10 \mathrm{~min}$, then at $42^{\circ} \mathrm{C}$ for $1 \mathrm{~h}$ and finally at $70^{\circ} \mathrm{C}$ for $15 \mathrm{~min}$ to inactivate the reaction. One tube without RNA and one with RNA, but without reverse transcriptase, were analysed as negative controls. To quantify the mRNA recovery 
rate, $5 \mathrm{pg}$ of luciferase mRNA (not subjected to RNA isolation) were subjected to cDNA synthesis as well.

\section{Real-time polymerase chain reaction}

Primers for all genes studied are listed in Table 1. Relative quantification of transcripts was performed by real-time polymerase chain reaction (RT-PCR) in a 7900HT Fast Real-Time PCR System (Applied Biosystems). The PCR was performed in a $15 \mu \mathrm{L}$ reaction volume containing $7.5 \mu \mathrm{L} 2 \times$ SYBR Green PCR Master Mix (Applied Biosystems), $200 \mathrm{nM}$ of each primer and cDNA equivalent to 0.25 oocyte/embryo. The PCR protocol comprised two incubation steps $\left(50^{\circ} \mathrm{C}\right.$ for $5 \mathrm{~min}$ and $95^{\circ} \mathrm{C}$ for $2 \mathrm{~min})$, followed by 40 cycles of amplification programme $\left(95^{\circ} \mathrm{C}\right.$ for $15 \mathrm{~s}$, gene-specific annealing temperature (Table 1 ) for $30 \mathrm{~s}$ and $72^{\circ} \mathrm{C}$ for $\left.30 \mathrm{~s}\right)$, a melting curve program $\left(65-95^{\circ} \mathrm{C}\right.$, starting fluorescence acquisition at $65^{\circ} \mathrm{C}$ and taking measurements at 10 -s intervals until the temperature reached $95^{\circ} \mathrm{C}$ ) and finally a cooling step to $4^{\circ} \mathrm{C}$. Fluorescence data were acquired during the $72^{\circ} \mathrm{C}$ extension steps. To minimize handling variation, all samples to be compared were run on the same plate using a PCR master mix containing all reaction components apart from the sample. PCR products were analysed by generating a melting curve to check the specificity and identity of the amplification product. For each primer pair, the efficiency of the PCR was determined by building a standard curve with serial dilutions of a known amount of template, covering at least 3 orders of magnitude, so that the calibration curve's linear interval included the interval above and below the abundance of the targets. Only primers achieving an efficiency of reaction between 90 and $110 \%(3.6>$ slope $>3.1)$ and a coefficient of determination $r^{2}>0.99$ were used for the analysis.

The sizes of the RT-PCR products were further confirmed by gel electrophoresis on a $2 \%$ agarose gel stained with SYBR Safe (Invitrogen) and visualised by exposing them to blue light. The PCR products were sequenced (Model 3130 xl Genetic Analyzer; Applied Biosystems) after purification with MinElute PCR purification kit (Qiagen) and sequence identities were confirmed with BLAST (http://www.ncbi.nlm.nih.gov/BLAST/).

The relative quantification of all transcripts was performed after normalization against luciferase mRNA levels and the number of oocytes and embryos (Su et al. 2007, Ohsugi et al. 2008, Evsikov et al. 2009).

\section{Immunofluorescence and confocal microscopy}

\section{Sample collection}

Methylation and hydroxymethylation immunostaining was performed on single oocytes and embryos obtained during several IVM, IVF and IVC sessions, as given in the following:

- Growing oocytes of different diameter (70/90, 90/110 and 110/130 $\mu \mathrm{m})$ derived from $\mathrm{P}$ animals.

- GV and IVM MII oocytes derived from P and A donors.

- IVP embryos at pronuclear (PN), two (2C) and four (4C) cell stage derived from $\mathrm{P}$ and $\mathrm{A}$ donors.

Table 1 Information on primers used for real-time PCR experiments.

\begin{tabular}{|c|c|c|c|c|}
\hline Gene & GenBank accession no. & Primers & Annealing temperature $\left({ }^{\circ} \mathrm{C}\right)$ & Size $(b p)$ \\
\hline$A C T B$ & NM_001009784 & $\begin{array}{l}\text { 5' TTCCTGGGTATGGATCCTG 3' } \\
\text { 5' GGTGATCTCCTTCTGCATCC 3' }\end{array}$ & 60 & 162 \\
\hline DNMT1 & NM_001009473 & $\begin{array}{l}\text { 5' CAGCTCTCGTACATCCACAG 3' } \\
\text { 5' AATCTCGCGTAGTCTTGGTC 3' }\end{array}$ & 60 & 158 \\
\hline DNMT3A & XM_015094252 & $\begin{array}{l}\text { 5' GTGATGATTGATGCCAAAGA 3' } \\
\text { 5' GGTCCTCACTTTGCTGAACT 3' }\end{array}$ & 60 & 165 \\
\hline DNMT3B & XM_012189044 & $\begin{array}{l}\text { 5' ATTGCAACAGGGTACTTGGT 3' } \\
\text { 5' ATATTTGATGTTGCCCTCGT 3' }\end{array}$ & 60 & 122 \\
\hline Luciferase & AF093685 & $\begin{array}{l}\text { 5' GCTGGGCGTTAATCAGAGAG 3' } \\
\text { 5' GTGTTCGTCTTCGTCCCAGT 3' }\end{array}$ & 58 & 151 \\
\hline$M B D 1$ & XM_015103744 & $\begin{array}{l}\text { 5' GAAGTGTCAGGTTGGACCTC 3' } \\
\text { 5' GATTGAAAGCGATCCTCTGT 3' }\end{array}$ & 60 & 209 \\
\hline$M B D 3$ & XM_015096029 & 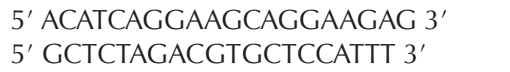 & 60 & 203 \\
\hline MBD4 & XM_012100228 & 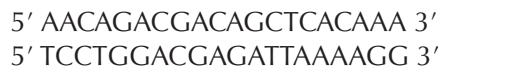 & 60 & 204 \\
\hline RLP19 & XM 004012836 & $\begin{array}{l}\text { 5'CAACTCCCGCCAGCAGAT 3' } \\
\text { 5' CCGGGAATGGACAGTCACA 3' }\end{array}$ & 56 & 127 \\
\hline$S D H A$ & XM_012097183 & $\begin{array}{l}\text { 5' CATCCACTACATGACGGAGCA 3' } \\
\text { 5' ATCTTGCCATCTTCAGTTCTGCTA 3' }\end{array}$ & 60 & 125 \\
\hline TET1 & XM_012105197 & $\begin{array}{l}\text { 5' CAGTATGCTCCAGCTGCTTA 3' } \\
\text { 5' TGCTCCCATTATTCATGTTG 3' }\end{array}$ & 60 & 166 \\
\hline TET2 & XM_015096388 & $\begin{array}{l}\text { 5' TACAAGAAACTCGCACCTGA 3' } \\
\text { 5' CTGCATGTTCTGCAAGTCTC 3' }\end{array}$ & 60 & 159 \\
\hline TET3 & XM_015094461 & $\begin{array}{l}\text { 5' TGGAGCATGTACTTCAATGG 3' } \\
\text { 5' GGTCACCTGGTTCTGATAGG 3' }\end{array}$ & 60 & 173 \\
\hline YWHAZ & NM_001135699 & $\begin{array}{l}\text { 5' TGTAGGAGCCCGTAGGTCATCT 3' } \\
5^{\prime} \text { TTCTCTCTGTATTCTCGAGCCATCT 3' }\end{array}$ & 60 & 168 \\
\hline
\end{tabular}

All accession numbers refer to Ovis aries, except for luciferase reporter vector pXP2*SA*PS. 
Anti-5-methylcytosine mouse mAb (5-mC; EMD Millipore's) and 5-hydroxymethylcytosine Rabbit (5-hmC; Active Motif) antibodies were used. Briefly, the oocytes were fixed in $4 \%$ paraformaldehyde for $20 \mathrm{~min}$, treated in $4 \mathrm{M} \mathrm{HCl}$ for $1 \mathrm{~h}$ and then neutralized in $100 \mathrm{mM}$ Tris$\mathrm{HCl}$ buffer $(\mathrm{pH} 8.5)$ for $10 \mathrm{~min}$. Subsequently, oocytes were incubated with propidium iodide $(50 \mu \mathrm{g} / \mathrm{mL})$ in PBS and blocked for non-specific binding in 30\% goat serum containing $0.05 \%$ Tween 20 in PBS. After extensive washing, the samples were incubated at $4{ }^{\circ} \mathrm{C}$ overnight with primary antibodies (1:200 dilution) followed with a fluorescein (Alexa Fluor 350 or 488)-conjugated antimouse or anti-rabbit IgG secondary antibody (1: 250; Alexa Fluor) at room temperature for $1 \mathrm{~h}$.

\section{Confocal analysis}

Immunofluorescence stain was evaluated using a TCS SP5 confocal laser scanning microscope (Leica) and the images were captured with the LAS AF lite application software (Leica). All the pictures were taken approximately in the equatorial z-plane of all developmental stages (GV and MII oocytes, zygotes and 2- and 4-cell stage embryos).

\section{Statistical analysis}

Gene expression data were analysed using the MINITAB Release 12.1 software package (Minitab Inc., State College, PA, USA). After testing for normality and equal variance using the Kolmogorov-Smirnov and Levene's tests respectively, transcript data were analysed with general linear model analysis of variance (ANOVA), followed by Tukey's post hoc comparisons when $P$ values were significant. Differences were considered significant when $P<0.05$.

\section{Results}

\section{Gene expression during oocyte growth}

To investigate DNA methylation dynamics during folliculogenesis, oocyte growth was divided into three main time intervals based on the gamete's largest diameter (70-90, 90-110 and 110-130 $\mu \mathrm{m})$.

The presence of all analysed transcripts during the investigated time frame of oocyte growth was confirmed. The relative quantification during oocyte growth allowed to discern the stages of oogenesis during which the molecules involved in methylation reprogramming are stored.

To get a better idea on the accumulation of transcripts during this window of oocyte growth, we relatively quantified the expression of four housekeeping genes (ACTB, SDHA, YWAHZ and RPL19) and observed no variations in abundance $(P>0.1)$, suggesting an earlier mRNA storage. Similarly, the transcript levels of DNMT3A, the three methyl-CpG-binding proteins (MBD1, MBD3 and MBD4) and TET2 showed no significant variation $(P>0.05)$. Conversely, DNMT1 and DNMT3B expression increased significantly during the initial growth $(D N M T 1)$ or during the whole analysed period (DNMT3B; Fig. 1) $(P<0.05)$. The accumulation of TET1 and TET3 mRNAs is in progress in S GO and is completed by the time oocytes reach the $90-110 \mu \mathrm{m}$ diameter (M GO).

\section{Gene expression during meiotic progression}

Messenger RNAs of evaluated genes were detected in GV and MII oocytes. No transcripts showed significant variation during meiotic progression in oocytes derived from adult (A) donors $(P>0.05)$. Conversely, TET1,
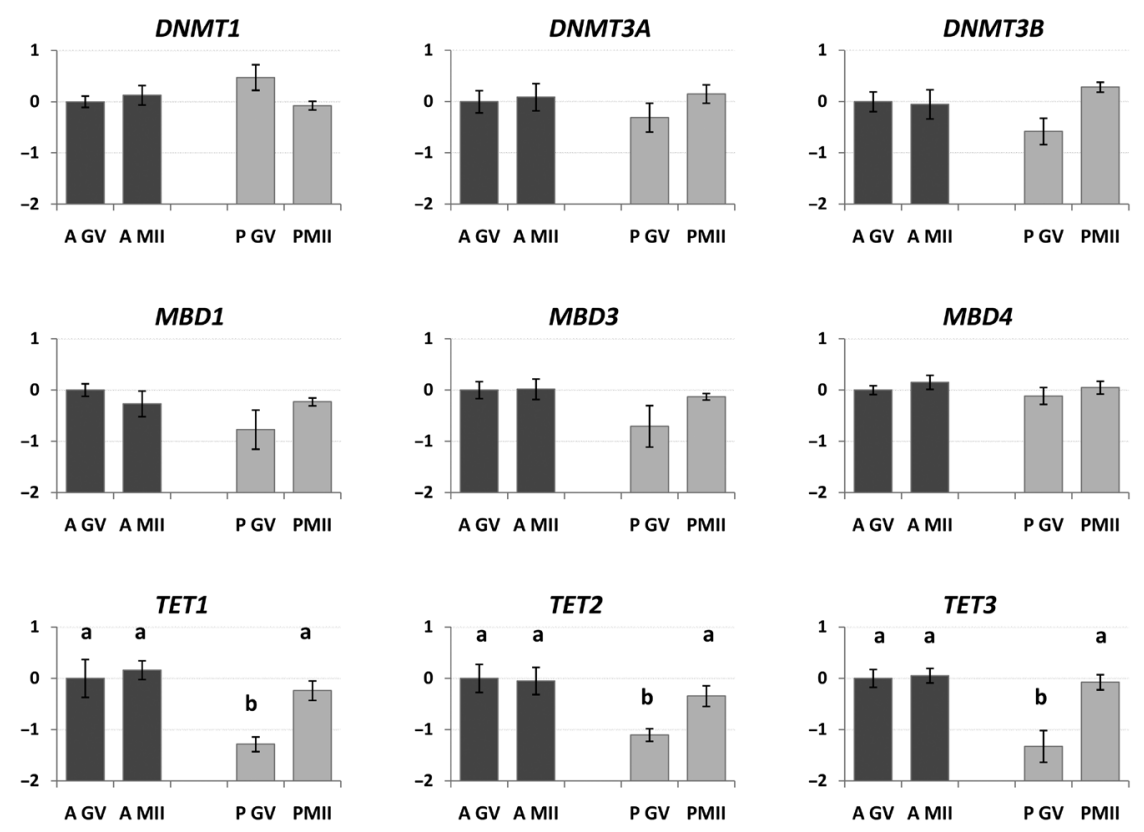

Figure 1 Relative expression of DNMT1, DNMT3A, DNMT3B, TET1, TET2, TET3, $M B D 1, M B D 3$ and $M B D 4$ in ovine growing oocytes (GO) at different diameter derived from pre-pubertal animals: 70-90 (small; S GO), 90-110 (medium; M GO) or 110$130 \mu \mathrm{M}$ (large; L GO) diameter. The relative quantification of all transcripts was performed after normalization against luciferase mRNA levels and the number of oocytes and embryos (Su et al. 2007, Ohsugi et al. 2008, Evsikov et al. 2009). Relative abundance values are expressed as $\Delta \mathrm{Cq}$ ( $Y$ axis) and show the mean value \pm S.E.M. of five replicates for each stage (each replicate $=$ pool of 30 oocytes). Different letters indicate a significant difference in relative mRNA abundance (ANOVA $P<0.05$ ) among the groups. 

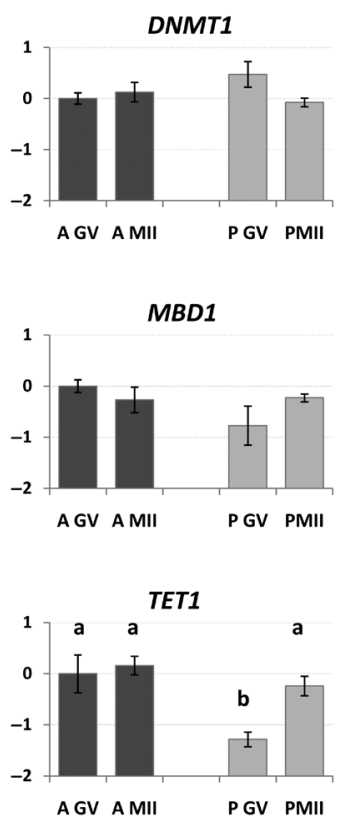
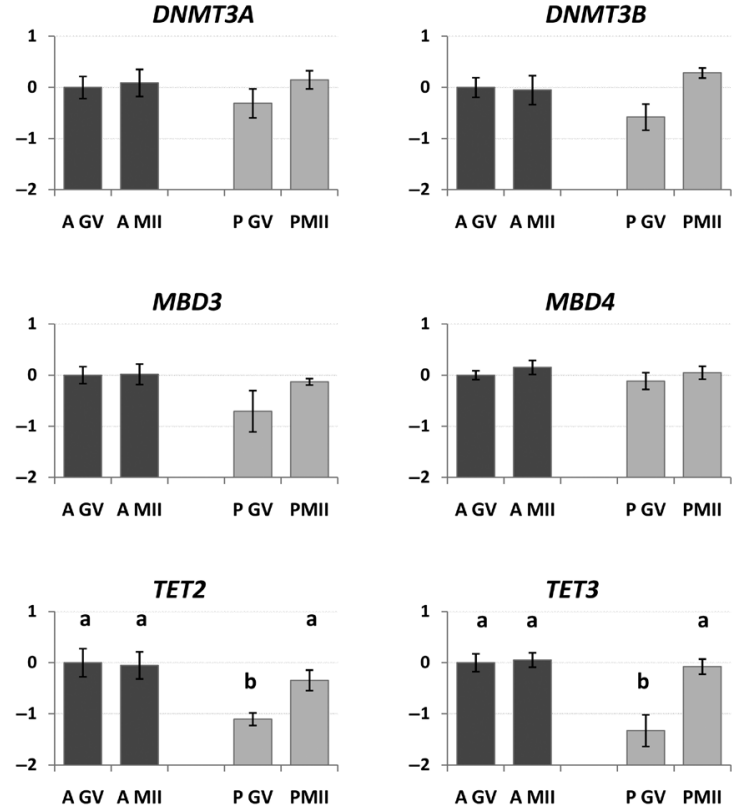

Figure 2 Relative expression of DNMT1, DNMT3A, DNMT3B, TET1, TET2, TET3, $M B D 1, M B D 3$ and $M B D 4$ in ovine immature GV and IVM MII oocytes derived from adult (A) or pre-pubertal (P) donors. The relative quantification of all transcripts was performed after normalization against Luciferase mRNA levels and the number of oocytes and embryos (Su et al. 2007, Ohsugi et al. 2008,

Evsikov et al. 2009). Relative abundance values are expressed as $\Delta \mathrm{Cq}$ ( $Y$ axis) and show the mean value \pm S.E.M. of five replicates for each stage (each replicate $=$ pool of 10 oocytes). Different letters indicate a significant difference in relative mRNA abundance (ANOVA $P<0.05$ ) among the groups.
TET2 and TET3 expression levels are significantly higher in pre-pubertal derived MII oocytes compared to GVs (Fig. 2) $(P<0.05)$. Furthermore, the comparison between pre-pubertal and adult derived gametes shows a significant difference at the GV stage $(P<0.05)$, with lower abundance in $P$ derived oocytes recovered after oocyte in vitro maturation (Fig. 2).

\section{Gene expression in embryos at 2 and 4 cell stage}

Transcripts of all genes were detected in both 2C and 4C embryos. No variation in any analysed mRNA level was observed between 2C and 4C adult derived embryos
$(P>0.05)$. A significant decrease in $M B D 1$ and $M B D 3$ transcript abundance was observed between $2 \mathrm{C}$ and $4 \mathrm{C}$ embryos derived from pre-pubertal donors $(P<0.05)$. $M B D 3$ expression varies significantly between $\mathrm{A}$ and $\mathrm{P}$ 4 cell embryos (Fig. 3).

\section{Global DNA methylation and hydroxymethylation analysis}

Except for growing oocytes, which were isolated from pre-pubertal ovaries, global DNA methylation and hydroxymethylation analysis were performed on oocytes and embryos derived from both adult and pre-pubertal
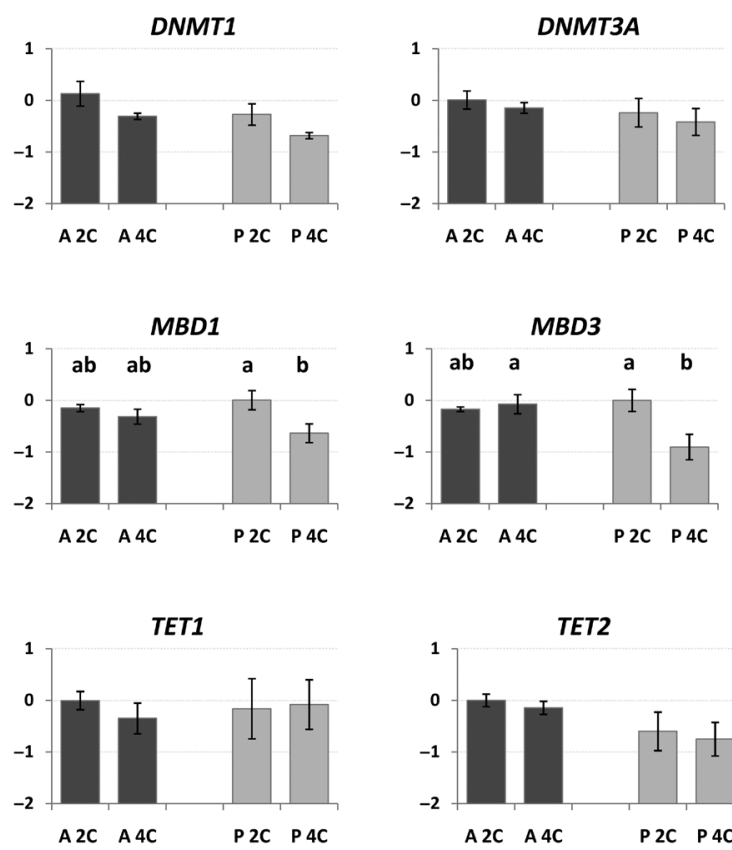
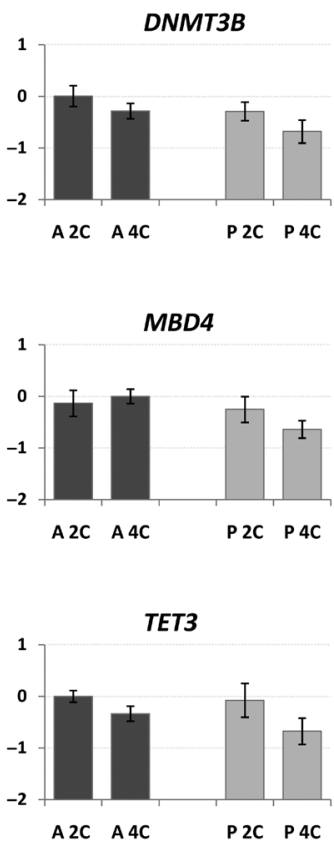

Figure 3 Relative expression of DNMT1, DNMT3A, DNMT3B, TET1, TET2, TET3, $M B D 1, M B D 3$ and $M B D 4$ in ovine in vitro produced two- $(2 \mathrm{C})$, four-cell $(4 \mathrm{C})$, embryos derived from adult (A) or pre-pubertal (P) donors. The relative quantification of all transcripts was performed after normalization against luciferase mRNA levels and the number of oocytes and embryos (Su et al. 2007, Ohsugi et al. 2008, Evsikov et al. 2009). Relative abundance values are expressed as $\Delta \mathrm{Cq}$ ( $Y$ axis) and show the mean value \pm S.E.M. of five replicates for each stage of development (each replicate $=$ pool of 10 embryos). Different letters indicate a significant difference in relative mRNA abundance (ANOVA, $P<0.05$ ) between developmental stages or between donor age. 
donors. As no differences were observed between the two sample sets, only images and descriptions of adult derived oocytes and embryos will be included below.

\section{Global DNA methylation and hydroxymethylation in growing oocytes}

Immunostaining of 5-mC revealed a strong staining in the three classes of analysed GO that overlapped with DNA staining (Fig. 4), suggesting that DNA methylation is mostly established in the oocyte at $70 \mu \mathrm{M}$ diameter and is widely distributed in the nucleus.

A weaker, but clearly visible 5 -hmC signal was also observed during the whole analysed timeframe of growth. The hydroxymethylation signal is not uniformly distributed throughout the chromatin, but it seems to cluster in restricted areas (Fig. 5).

\section{Global DNA methylation and hydroxymethylation during meiotic progression}

High levels of DNA methylation were detected by immunofluorescence analysis in GV and MII stage oocytes (Fig. 6). DNA hydroxymethylation signal was evident, but weaker compared to 5-mC, and it still seems to be clustered in areas throughout the oocyte chromatin (Fig. 7).

\section{Global DNA methylation and hydroxymethylation during early embryonic development}

Staining of $5-\mathrm{mC}$ in embryos at the zygote stage revealed considerable levels of DNA methylation in both pronuclei with an apparently weaker signal in male PN compared to the female one (Fig. 8). Conversely, 5-hmC signal is restricted to the paternal PN, while only a faint signal can be recognized in the maternal one (Fig. 9). The signal in paternal PN maintains the peculiar scattered distribution, but is stronger compared to what was observed in oocytes and embryos at further stages. In 2- and 4-cell embryos, in fact, the intensity of 5-hmC signal decreases, while the methylation level seems to maintain a considerable strength (Fig. 9). A change in 5-mC pattern was observed between 2-cell and 4-cell stage, with a more evenly distributed signal in younger embryos and the presence of clusters with a stronger intensity in the older ones (Fig. 8).

\section{Discussion}

Three main novel findings emerged from our study. First, we report temporal methylation dynamics during ovine oocyte growth in terms of global methylation, hydroxymethylation and expression of the enzymes involved in their remodelling. Second, we show differences in methylation and hydroxymethylation

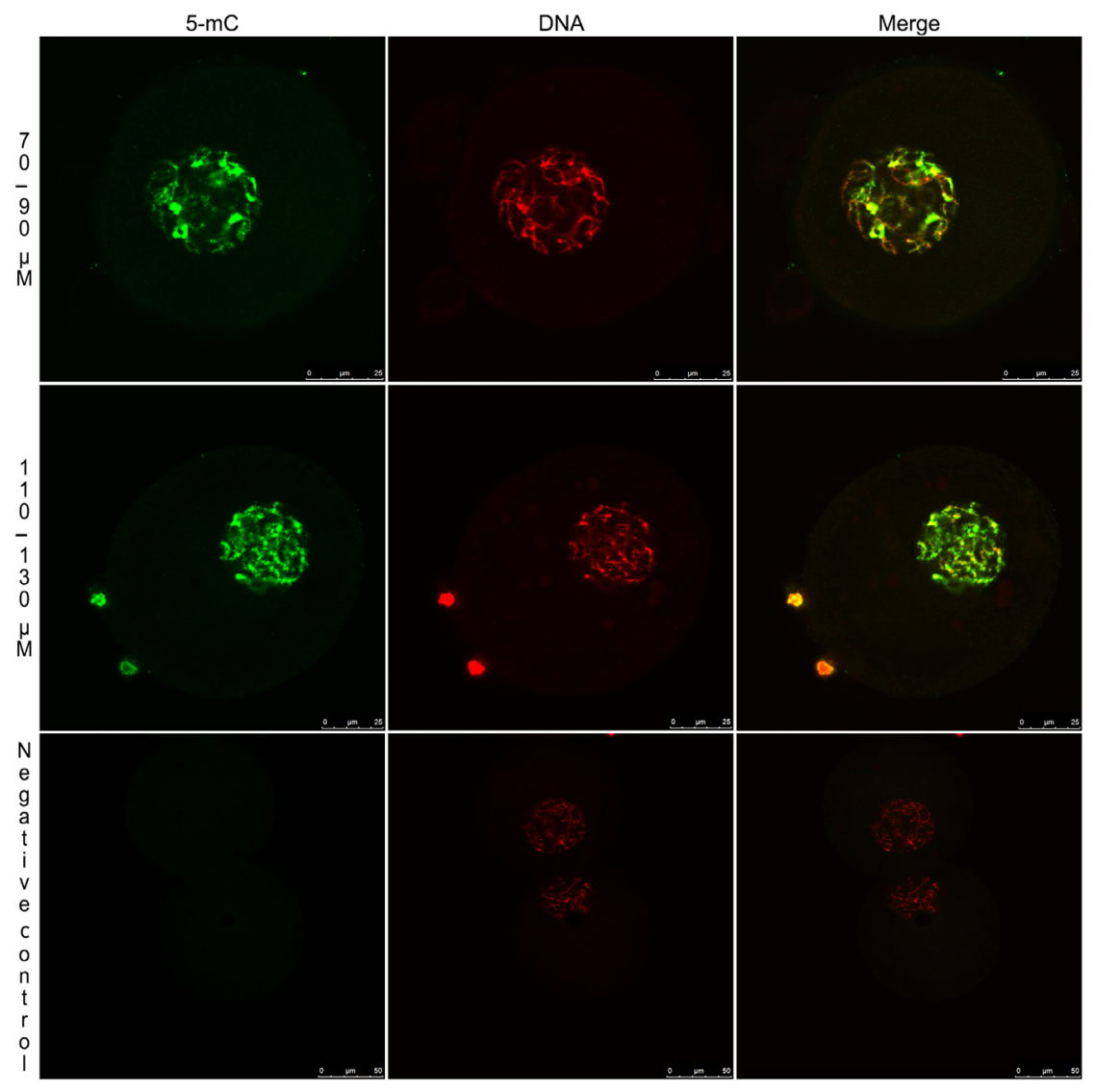

Figure 4 Immunofluorescent localization of 5-methylcytosine (5-mC) and negative control in freshly collected growing oocytes at different diameter $(70 / 90 \mu \mathrm{m}$ and $110 / 130 \mu \mathrm{m})$ derived from pre-pubertal animals. DNA was stained with propidium iodide and is shown in red. The scale bar represents $25 \mu \mathrm{m}$. 

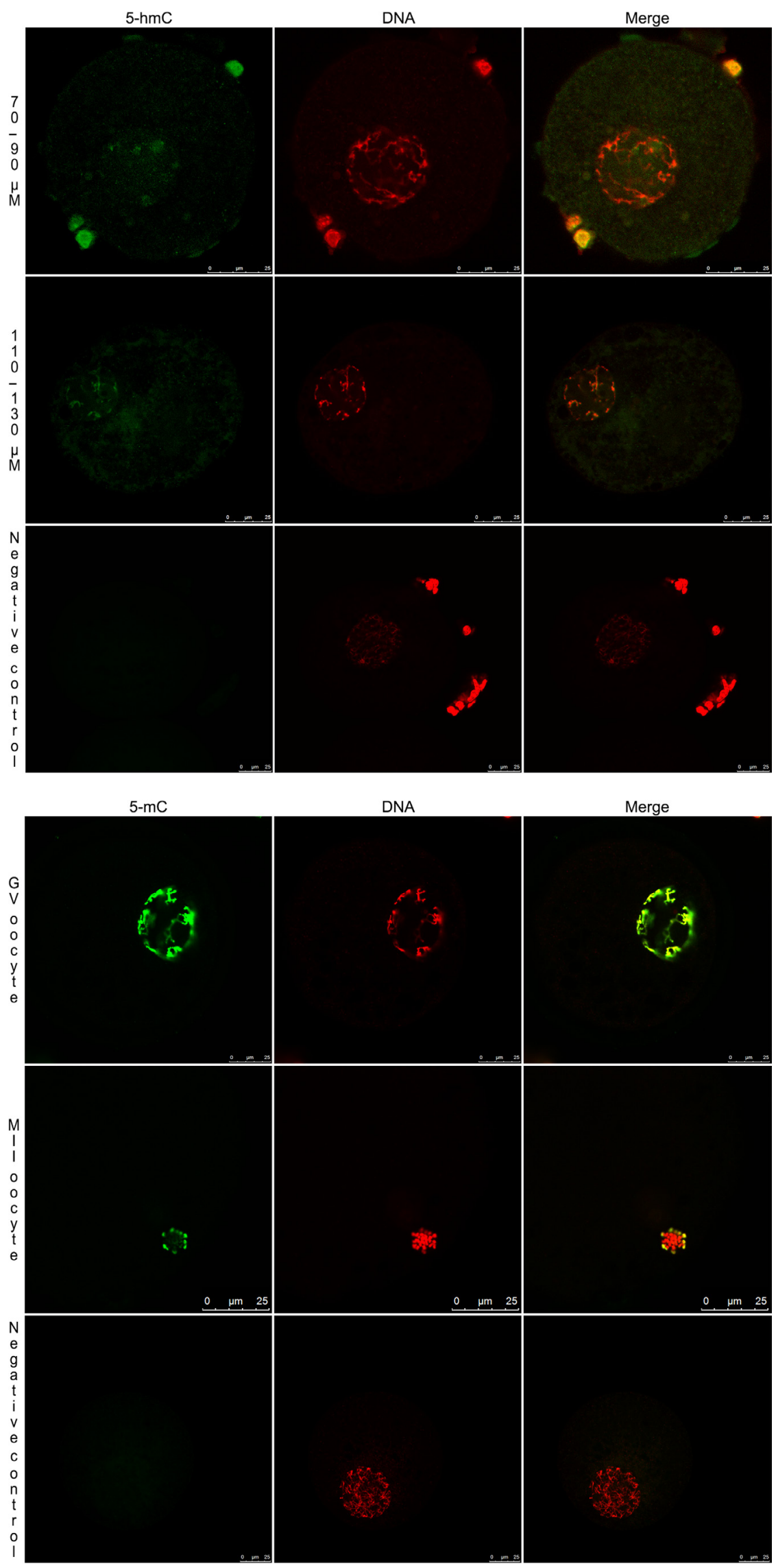

Figure 5 Immunofluorescent localization of 5-hydroxylmethylcytosine (5-hmC) and negative control in freshly collected growing oocytes at different diameter $(70 / 90 \mu \mathrm{m}$ and $110 / 130 \mu \mathrm{m}$ ) derived from pre-pubertal animals. DNA was stained with propidium iodide and is shown in red. The scale bar represents $25 \mu \mathrm{m}$.
Figure 6 Immunofluorescent localization of 5-methylcytosine (5-mC) and negative control in freshly collected GV and MII oocytes derived from adult animals. DNA was stained with propidium iodide and is shown in red. The scale bar represents $25 \mu \mathrm{m}$. 


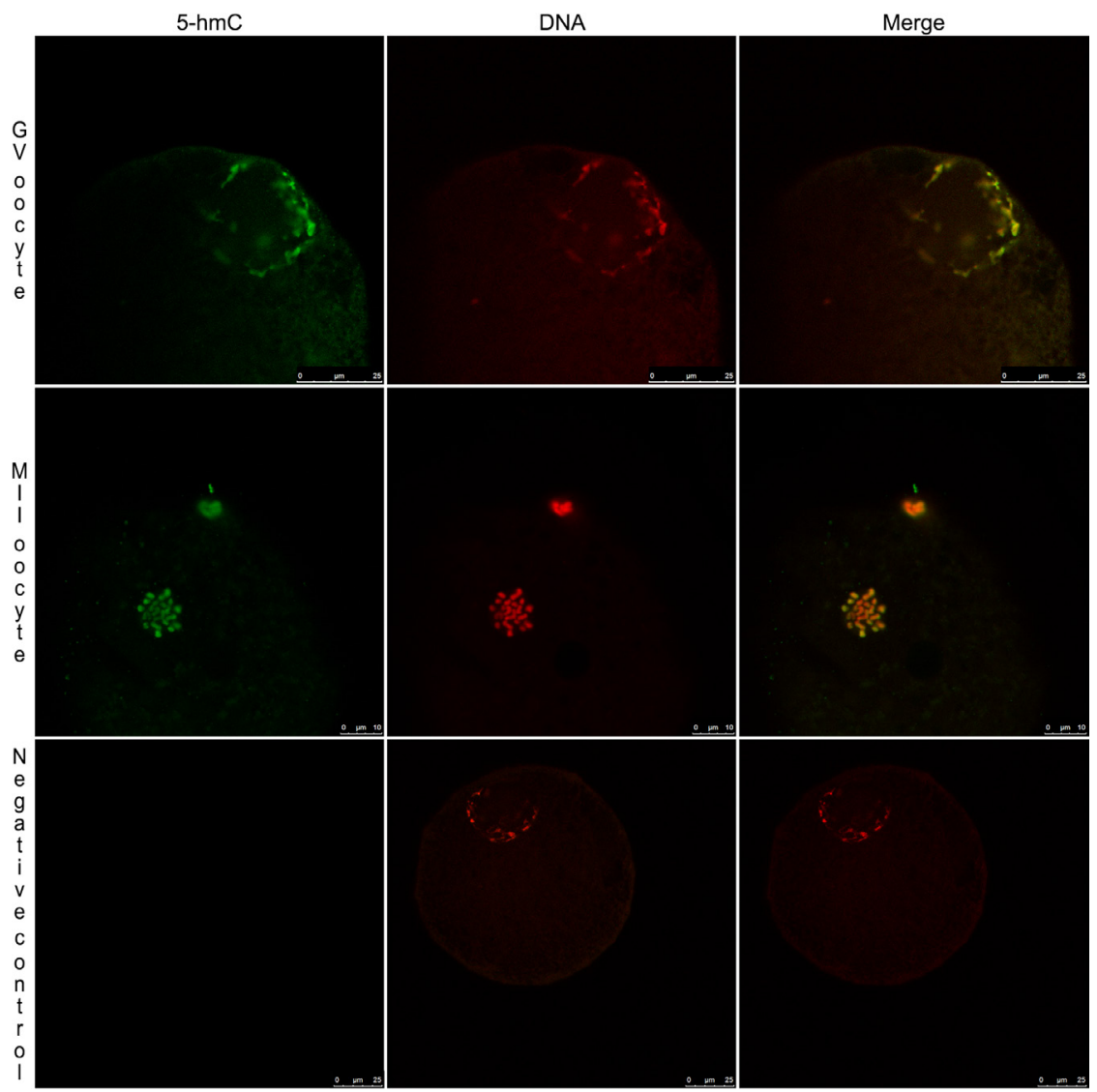

Figure 7 Immunofluorescent localization of 5-hydroxylmethylcytosine (5-hmC) and negative control in freshly collected GV and MII oocytes derived from adult animals. DNA was stained with propidium iodide and is shown in red. The scale bar represents $25 \mu \mathrm{m}$.

patterns between male and female pronucleus (PN) that suggest an active demethylation of male PN also in sheep. Third, we identified altered expression of TET1, TET2 and TET3, and MBD1 and MBD3 in low quality oocytes and embryos respectively, in a differential model of developmental competence.

To investigate DNA methylation dynamics during folliculogenesis, oocyte growth was divided into three main time intervals based on the gamete's largest

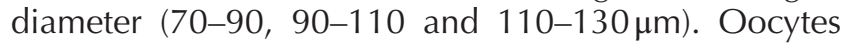
derived from four weeks old lambs were used for the analysis in order to minimize any possible variation of the oocyte epigenetic status due to potential changes in the environment (i.e. nutrition, pathologies or accidental exposition to various contaminants; Cortessis et al. 2012).

Analysis of DNA methylation during oocyte growth showed high methylation at all analysed stages that overlapped with DNA staining (Fig. 4), suggesting that de novo DNA methylation is mostly concluded when the oocyte reaches $70 \mu \mathrm{m}$ diameter and is widely distributed in the nucleus. Our results are in partial agreement with a previous work (Russo et al. 2007) reporting 5 -mC immunopositivity in growing ovine oocytes with a diameter of at least $90 \mu \mathrm{m}$; the difference related to oocytes with 70-90 $\mu \mathrm{m}$ diameter could be explained by the improved affinity of the antibodies available nowadays or to the different immunostaining protocol used.

Analysis of hydroxymethylation, not previously reported in ovine growing oocytes, revealed a weaker, but clearly visible signal. Interestingly, the signal is not uniformly distributed throughout the chromatin, but seems to cluster in restricted areas (dot-like; Fig. 5) as described in growing oocytes in mouse (Yamaguchi et al. 2013, Sakashita et al. 2014).

The molecules that will support oocyte maturation, fertilization and early embryo development are stored during oocyte growth, as these events happen in the absence of de novo transcription. In addition, postfertilization epigenetic reprogramming occurs during transcriptional quiescence therefore it relies on the enzymes and co-factors deposited in the gamete during its growth. Messenger RNAs and proteins are stored in a temporally regulated manner during folliculogenesis. Our analysis allowed to discern during which stages of oogenesis the stocks of the molecules involved in methylation reprogramming are formed. Expression analysis of the methylating enzymes DNMT1 and DNMT3B showed a significant increase during oocyte growth in relation to its diameter, highlighting an ongoing transcription (Fig. 1) in accordance with reports in mouse and bovine (Ratnam et al. 2002, Lucifero et al. 2007, Bessa et al. 2013). Conversely, DNMT3A abundance 


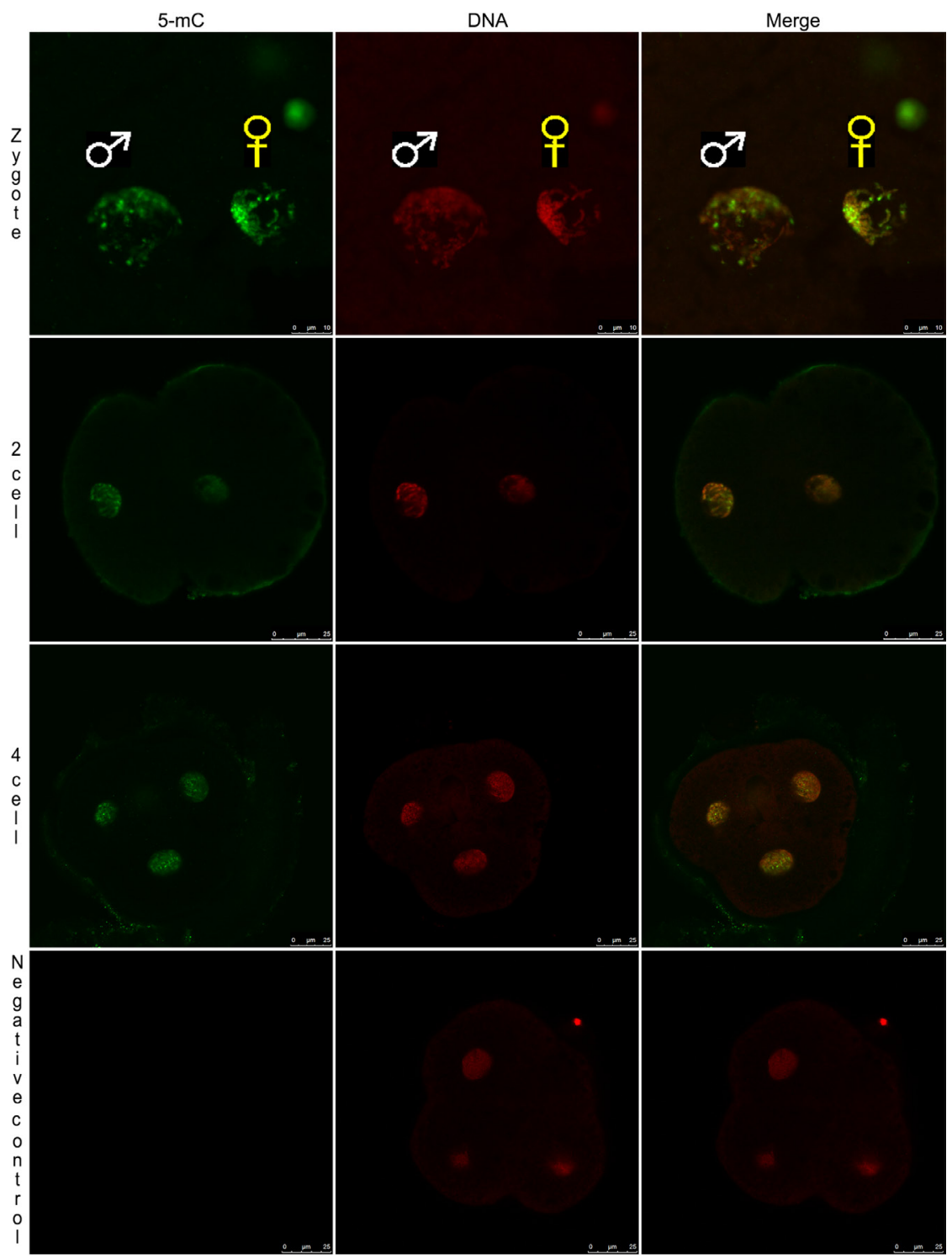

Figure 8 Immunofluorescent localization of 5-methylcytosine (5-mC) and negative control in in vitro matured and fertilized zygotes, 2-cell and 4-cell embryos. DNA was stained with propidium iodide and is shown in red. The scale bar represents $25 \mu \mathrm{m}$. did not vary significantly, suggesting that the transcript accumulation may be already completed because of its early need during gamete growth. DNMT3A is in fact responsible of establishing new methylation patterns in the oocytes and was seen to be essential for methylation of both maternally and paternally imprinted genes (Kaneda et al. 2004). Its activity is most probably responsible for the high level of methylation already observed in oocytes with $70 \mu \mathrm{m}$ diameter.

Expression analysis of the three known dioxygenases TET1, TET2 and TET3 showed a significant increase in TET1 and TET3 abundance during the first analysed phase (up to about $100 \mu \mathrm{m}$ ), while TET2 transcript did not vary significantly throughout the analysed time frame. Studies in mouse, bovine, rabbit and pig reported different and sometimes contradictory patterns of TET1, TET2 and TET3 expressions during oogenesis and early development. A consensus regards Tet 3 very high expression in the oocyte and zygote in all species (Iqbal et al. 2011, Wossidlo et al. 2011, Lee et al. 2014, Page-Lariviere \& Sirard 2014, Sakashita et al. 2014, Salvaing et al. 2016), while data on Tet1 and Tet2 are inconsistent. Sakashita and coworkers (Sakashita et al. 2014) reported a significant increase in Tet 3 expression during mouse oocyte growth, but failed to report the expression of Tet1 or Tet2 in growing or GV oocytes. Similarly, Iqbal and coworkers (Iqbal et al. 2011) observed Tet3, but not Tet1 or Tet2, high expression in mouse oocytes and zygotes that was drastically down regulated at the two-cell stage; however, they detected Tet 1 at low levels in the two- and four-cell stage embryo. On the other hand, different works succeeded in observing Tet1 and Tet 2 expressions in mouse oocytes and zygotes, even if low or moderate (Ito et al. 2010, Wossidlo et al. 2011). In bovine oocytes, TET2 expression was reported at very low levels and TET1 expression could not be detected 


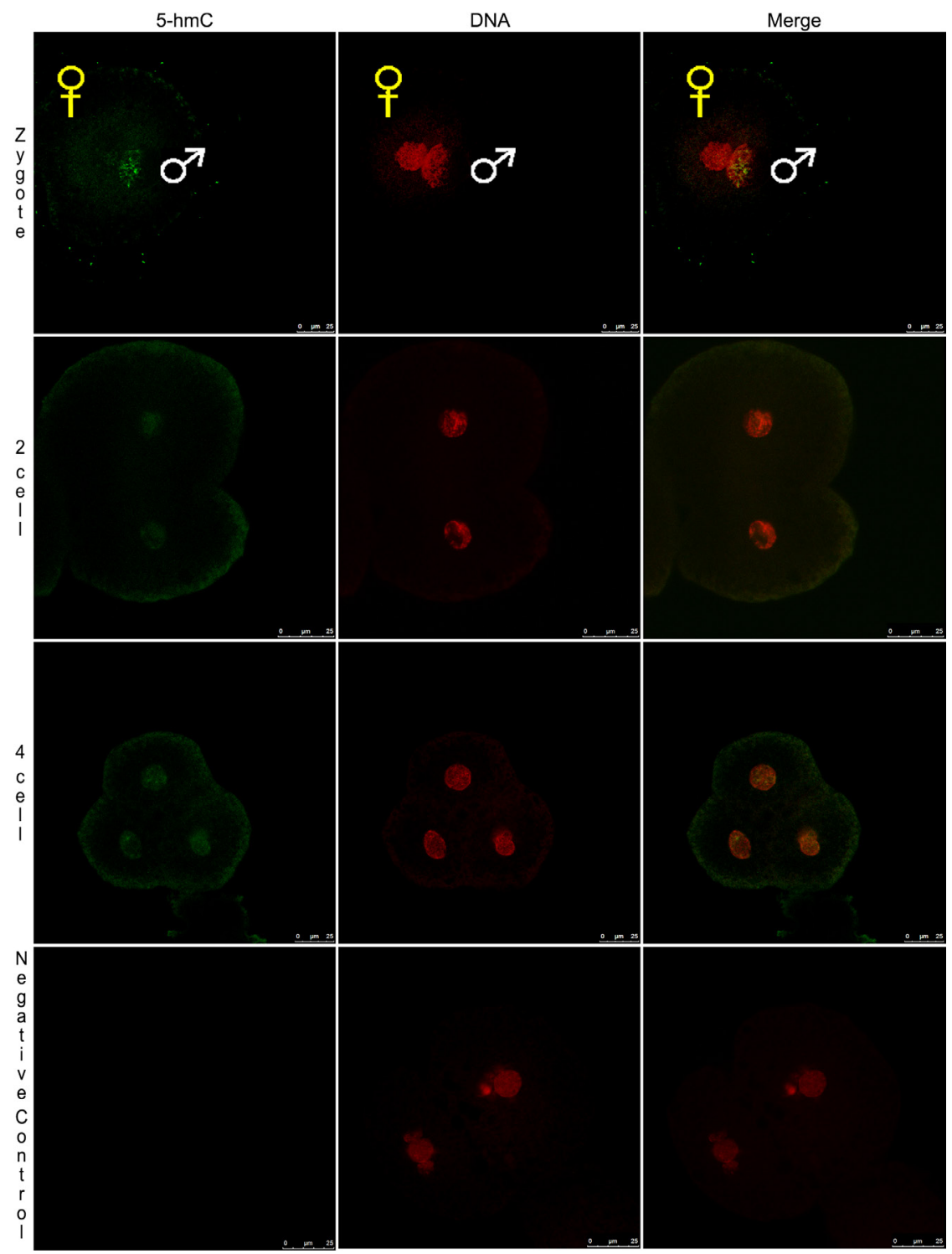

Figure 9 Immunofluorescent localization 5-hydroxylmethylcytosine (5-hmC) and negative control in in vitro matured and fertilized zygotes, 2-cell and 4-cell embryos. DNA was stained with propidium iodide and is shown in red. The scale bar represents $25 \mu \mathrm{m}$.
(Page-Lariviere \& Sirard 2014). Low TET1 mRNA abundance was described in oocytes and early embryos in both pig and rabbit (Lee et al. 2014, Salvaing et al. 2016). Conversely, TET2 was seen to be moderately expressed during oocyte maturation and early embryo pre-implantation in pig, but its higher abundance was reported in rabbit oocytes and 1- to 4-cell stage embryos (Salvaing et al. 2016). We first observed the presence of TET1-3 transcripts in the growing oocyte, which persisted during oocyte maturation and in the early embryo (2- and 4-cell stage). While no absolute quantification was performed, the relative quantification with similar amplification efficiency $\left(R^{2}>0.99\right)$ and the same amount of cDNA template indicate the highest abundance for TET3, a lower expression for TET2 (about $25 \%$ of TET3 expression) and the lowest level for TET1 (about $4 \%$ of TET3 expression) in GV oocytes, confirming the trend observed in the other species
(Fig. 10). The longer persistence of the transcripts we observed in ovine early embryos compared to mouse are most probably due to the higher number of cell cycles required in sheep for embryo genome activation (EGA; Fig. 3). Indeed, the activation of the genome at the 8- to 16-cell stage expands the time frame available for the regulation of gene expression and allows an easier observation (Ledda et al. 2012).

The distinct expression pattern of TET1-3 we observed during oogenesis supports the hypothesis of non-overlapping biological functions that vary in a developmentally regulated and tissue-specific manner (Wu \& Zhang 2011); however, the specific functions are yet to be clarified, as evidenced by the most recent literature. Currently, the accepted model for active DNA demethylation identifies Tet3 as the enzyme mostly responsible for the global loss of 5-mC that takes place in the paternal genome shortly after fertilization 


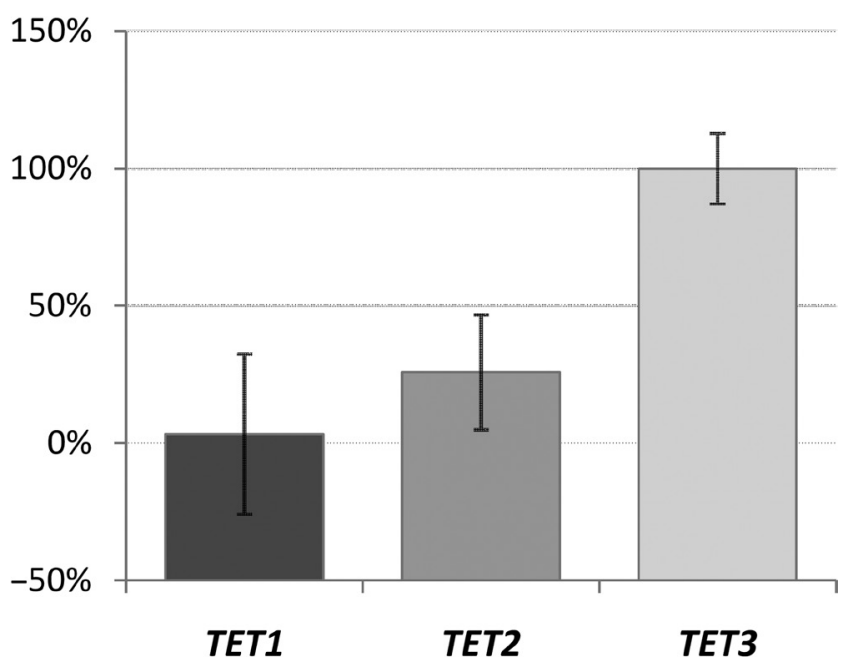

Figure 10 Relative mRNA abundance of TET1, TET2 and TET3 in GV oocytes as shown by RT-PCR analysis. Values are expressed in percentages; TET3 abundance was set to $100 \%$ and TET1 and TET2 expressed relatively to TET3. The relative quantification was performed with similar amplification efficiencies $\left(R^{2}>0.99\right)$ and same amount of cDNA template (0.5 embryo equivalent).

(Mayer et al. 2000). Recent data showed that Tet3 contributes to 5-mC oxidation also in the maternal genome (Shen et al. 2014), although to a lesser extent compared to the paternal DNA. However, the overall picture is continuously evolving and the latest results challenge Tet3 involvement in the initial loss of paternal PN 5-mC signal that may occur even in the absence of the enzyme hydroxylation activity (Dawlaty et al. 2013). TET1 and TET2 are also involved in hydroxymethylation, but information on their specific function is more limited. The expression of either enzyme was seen to compensate for deficiency of the other during development (Du et al. 2015); however, their different expression pattern in mouse oocyte (Wossidlo et al. 2011) and in the present work suggests the existence of individual functions for the two proteins that are yet to be identified.

Analysis of MBD1, MBD3 and MBD4 expressions showed no variation during the considered oocyte growth. Comparison with abundance at the GV stage suggests that the synthesis of the three mRNAs was completed during early oocyte growth and did not increase significantly in oocytes with diameter $>70 \mu \mathrm{m}$. These observations support an early need for the co-factors during oocyte growth, in accordance with their involvement in the regulation and interpretation of DNA methylation and transcription (Du et al. 2015).

Analysis of gene expression during oocyte maturation showed no variation in mRNA abundance between GV and MII stages in oocytes derived from adult donors, in accordance with observations during meiotic progression of fully grown oocytes in mouse and pig (Lee et al. 2014, Sakashita et al. 2014). However, analysis of the transcripts in a model of differential developmental competence revealed an association between TET enzyme expression and oocyte quality. We have adopted a previously developed model consisting of ovine oocytes deriving from adult (A) vs prepubertal $(\mathrm{P})$ donors to study high vs low developmental competence respectively (reviewed in Ledda et al. 2012). The differential quality of the two types of gametes was proven in different species and refers to several aspects comprising resistance to cryopreservation (Leoni et al. 2006), transcript abundance (Leoni et al. 2007, Romar et al. 2011, Ledda et al. 2012), in vitro kinetic development (Leoni et al. 2006, 2015), mitochondrial distribution (Leoni et al. 2015) and the ability to give birth to live offspring (Armstrong et al. 1997, Ledda et al. 1999). Analysis of the transcripts in our model showed lower levels of the three TET transcripts in GV oocytes derived from young animals compared to GV oocytes derived from adult donors, but similar expression levels in $\mathrm{P}$ and $\mathrm{A}$ oocytes at the MII stage (Fig. 2). Such pattern suggests a delay in the synthesis and storage of TET transcripts in the pre-pubertal oocytes at the GV stage, which is recovered by the end of oocyte maturation, when differences disappear (Fig. 2). A transcriptional activity in GV has already been proposed in pre-pubertal mouse (Chouinard 1971), bovine (Fair et al. 1995) and sheep (Ptak et al. 2006). We have previously shown differences in mRNA abundance at GV stage between pre-pubertal and adult ovine oocytes (Leoni et al. 2007). The observations in the present work confirm the hypothesis that oocytes from juvenile animals have an incomplete molecular deposit (RNAs and proteins) that may affect competence acquisition, which involves deficiencies in the methylation machinery.

Immunofluorescence analysis of the global DNA methylation and hydroxymethylation during meiotic progression showed signal intensity and distribution similar to what was observed during oocyte growth (Figs 6 and 7). No variation depending on meiotic progression or donor origin was observed. However, the presence of subtle differences that are not detectable by immunostaining cannot be excluded.

Staining of $5-\mathrm{mC}$ in embryos at the zygote stage revealed the presence of DNA methylation in both $\mathrm{PN}$, with an apparently weaker signal in male PN compared to that of the female PN (Fig. 8). Conversely, hydroxymethylation signal is restricted to the paternal $\mathrm{PN}$, while only a faint signal can be recognized in the maternal one (Fig. 9), in accordance with observations in mouse, bovine and rabbit zygotes (Wossidlo et al. 2011). The staining of paternal PN is stronger compared to what was observed in oocytes or embryos at further stages, but maintains the peculiar scattered distribution (Fig. 9). The observations of 5-mC and 5-hmC patterns in zygotes suggest for the first time that male pronucleus undergoes active demethylation also in sheep. Our results contrast with a previous report (Young \& Beaujean 2004) that showed no loss of 5-mC staining in sheep paternal 
genome within the first post-fertilization cell cycle and postulated sheep escape from the conventional model of early embryo epigenetic reprogramming observed in most mammalian species. The model proposes a strong active demethylation of the male PN soon after fertilization and a passive loss of methylation in the female PN through cell cycles (Mayer et al. 2000). The decrease in 5-mC that was observed in male $\mathrm{PN}$ in sheep is consistent with genome-wide DNA methylation data recently obtained in mouse and bovine (De Montera et al. 2013, Wang et al. 2014).

Immunofluorescence analysis in embryos at 2- and 4-cell stage evidenced immunopositivity for both 5-mC and 5-hmC antibodies; however, hydroxymethylation considerably decreased compared to the previous stages. The subnuclear localization pattern of 5-mC changed, with a restriction of the signal to limited foci that show stronger intensity in the 4-cell stage embryos (Fig. 8).

Expression analysis in embryos at 2- and 4-cell stage evidenced constant levels in mRNA abundance; however, low quality embryos in the differential model show a decrease in mRNA abundance for MBD1 and MBD3 (Fig. 3). Although identifying the reason for the observed reduction may be challenging before the specific functions of the two proteins in the early embryos are clarified, the patterns of expression suggest a different regulation of the two transcripts (increased translation or degradation) that may affect the embryo development.

The dynamics of hydroxymethylation we observed during late oogenesis and early embryo development suggest a role for 5 -hmC other than just being a transient status during demethylation. The presence of $5-\mathrm{hmC}$ during oocyte growth, together with stable levels of methylation, hints an additional biological role, as indicated by very recent evidence that show active demethylation of the paternal PN uncoupled from hydroxymethylation of the genome (Amouroux et al. 2016). In accordance, DNA methylation and hydroxymethylation were seen to co-exist in nonreciprocal patterns in human oocytes (Petrussa et al. 2016) and in both pronuclei of human (Petrussa et al. 2016) and mouse zygotes (Salvaing et al. 2012). In agreement with a potential role in the regulation of transcription (Kang et al. 2015), previous studies have established that hydroxymethylated and methylated DNA have different binding properties with co-factors involved in transcription regulation; for instance, the interaction of MBD proteins with 5-mC is abolished by hydroxymethylation (Valinluck et al. 2004). This implies that these two epigenetic modifications perform distinct biological functions. It is possible that the genomic content of 5-hmC could contribute to the regulation of expression of specific genes during development and differentiation by modulating the open or closed state of the chromatin (Ruzov et al. 2011).
The role of $5 \mathrm{hmC}$ in epigenetic reprogramming during female germ line cell development is not fully understood; yet, it is indeed probable that the areas with high 5-hmC are linked to substantial transcription and are less likely to demethylation in this stage of oocyte growth, when significant stores of mRNAs have to be accumulated and DNA methylation reestablishment is ongoing.

The results of the present study differ from a recent work (Fang et al. 2016) that investigated a restricted panel of enzymes involved in DNA methylation remodelling in relation to oocyte developmental capacity in sheep. The work reported lower levels of mRNA in GV, MII stage oocyte, zygotes and $2 \mathrm{C}$ embryos derived from pre-pubertal animals compared with the same stage of development derived from adult donors. However, the study was performed on oocytes and deriving embryos collected from hormonally treated animals (both young and adult donors), while in the present study the gametes were obtained from non-treated donors. Such crucial diversity, which is upstream of the entire experiment, is most likely responsible for the observed differences in gene expression, as repeatedly reported (MarketVelker et al. 2010, Chu et al. 2012, Urrego et al. 2014).

In conclusion, our work showed methylation dynamics during folliculogenesis and early embryo development in sheep. Our findings suggest an active DNA demethylation of the paternal pronucleus also in sheep, supporting the conservation of the mechanism in mammals and advancing the understanding of the reprogramming process that involves DNA methylation/ demethylation.

The overall description of DNA methylation dynamics in growing oocytes could be useful to identify potential epigenetic alterations caused by assisted reproductive procedures, in order to optimize protocols and contribute to generate fully viable and healthy offspring.

\section{Declaration of interest}

The authors declare that there is no conflict of interest that could be perceived as prejudicing the impartiality of the research reported.

\section{Funding}

This work was supported by Regione Autonoma della Sardegna under grant 'Legge 7/2007 - Bando 2012, CRP 60208, CUP F71J12000900002 - RAS' and by the COST action FA 1201 'Epigenetics and Periconception Environment'.

\section{Acknowledgements}

D B is the recipient of an RTD contract at the University of Sassari, Italy, for the project 'Embryo mortality in the ovine species: identification of the factors responsible for pregnancy 
failures' granted by 'P.O.R. SARDEGNA F.S.E. 2007-2013 Obiettivo competitività regionale e occupazione, Asse IV Capitale umano, Linea di Attività I.3.1'.

\section{References}

Amouroux R, Nashun B, Shirane K, Nakagawa S, Hill PW, D'Souza Z, Nakayama M, Matsuda M, Turp A, Ndjetehe E et al. 2016 De novo DNA methylation drives $5 \mathrm{hmC}$ accumulation in mouse zygotes. Nature Cell Biology 18 225-233. (doi:10.1038/ncb3296)

Armstrong DT, Kotaras PJ \& Earl CR 1997 Advances in production of embryos in vitro from juvenile and prepubertal oocytes from the calf and lamb. Reproduction Fertility Development 9 333-339. (doi:10.1071/ R96080)

Beaujean N, Hartshorne G, Cavilla J, Taylor J, Gardner J, Wilmut I, Meehan R \& Young L 2004 Non-conservation of mammalian preimplantation methylation dynamics. Current Biology 14 R266-R267. (doi:10.1016/j.cub.2004.03.019)

Bessa IR, Nishimura RC, Franco MM \& Dode MA 2013 Transcription profile of candidate genes for the acquisition of competence during oocyte growth in cattle. Reproduction in Domestic Animals 48 781-789. (doi:10.1111/rda.12162)

Bestor T, Laudano A, Mattaliano R \& Ingram V 1988 Cloning and sequencing of a cDNA encoding DNA methyltransferase of mouse cells. The carboxyl-terminal domain of the mammalian enzymes is related to bacterial restriction methyltransferases. Journal of Molecular Biology 203 971-983. (doi:10.1016/0022-2836(88)90122-2)

Bogliolo L, Ariu F, Leoni G, Uccheddu S \& Bebbere D 2011 High hydrostatic pressure treatment improves the quality of in vitro-produced ovine blastocysts. Reproduction, Fertility and Development 23 809-817. (doi:10.1071/RD11023)

Bourc'his D, Xu GL, Lin CS, Bollman B \& Bestor TH 2001 Dnmt3L and the establishment of maternal genomic imprints. Science 294 2536-2539. (doi:10.1126/science.1065848)

Bustin SA, Benes V, Garson JA, Hellemans J, Huggett J, Kubista M, Mueller R, Nolan T, Pfaffl MW, Shipley GL et al. 2009 The MIQE guidelines: minimum information for publication of quantitative realtime PCR experiments. Clinical Chemistry 55 611-622. (doi:10.1373/ clinchem.2008.112797)

Chen T \& Li E 2004 Structure and function of eukaryotic DNA methyltransferases. Current Topics in Developmental Biology 60 55-89. (doi:10.1016/S0070-21530460003-2)

Chouinard LA 1971 A light- and electron-microscope study of the nucleolus during growth of the oocyte in the prepubertal mouse. Journal of Cell Science 9 637-663.

Chu T, Dufort I \& Sirard MA 2012 Effect of ovarian stimulation on oocyte gene expression in cattle. Theriogenology 77 1928-1938. (doi:10.1016/j. theriogenology.2012.01.015)

Cortessis VK, Thomas DC, Levine AJ, Breton CV, Mack TM, Siegmund KD, Haile RW \& Laird PW 2012 Environmental epigenetics: prospects for studying epigenetic mediation of exposure-response relationships. Human Genetics 131 1565-1589. (doi:10.1007/s00439-012-1189-8)

Dawlaty MM, Breiling A, Le T, Raddatz G, Barrasa MI, Cheng AW, Gao Q, Powell BE, Li Z, Xu M et al. 2013 Combined deficiency of Tet1 and Tet2 causes epigenetic abnormalities but is compatible with postnatal development. Developmental Cell 24 310-323. (doi:10.1016/j. devcel.2012.12.015)

De Montera B, Fournier E, Shojaei Saadi HA, Gagné D, Laflamme I, Blondin P, Sirard MA \& Robert C 2013 Combined methylation mapping of $5 \mathrm{mC}$ and $5 \mathrm{hmC}$ during early embryonic stages in bovine. BMC Genomics 14 406. (doi:10.1186/1471-2164-14-406)

Du Q, Luu PL, Stirzaker C \& Clark SJ 2015 Methyl-CpG-binding domain proteins: readers of the epigenome. Epigenomics 7 1051-1073. (doi:10.2217/epi.15.39)

Evsikov AV \& Marín de Evsikova C 2009 Gene expression during the oocyte-to embryo transition in mammals. Molecular Reproduction and Development 76 805-818. (doi:10.1002/mrd.21038)

Fair T, Hyttel P \& Greve T 1995 Bovine oocyte diameter in relation to maturational competence and transcriptional activity. Molecular Reproduction and Development 42 437-442. (doi:10.1002/ mrd.1080420410)
Fang Y, Zhang X, Zhang J, Zhong R \& Zhou D 2016 Global DNA methylation and related mRNA profiles in sheep oocytes and early embryos derived from pre-pubertal and adult donors. Animal Reproduction Science $\mathbf{1 6 4}$ 144-151. (doi:10.1016/j.anireprosci.2015.11.022)

Gu P, Le Menuet D, Chung AC \& Cooney AJ 2009 Differential recruitment of methylated CpG binding domains by the orphan receptor GCNF initiates the repression and silencing of Oct4 expression. Molecular and Cellular Biology 29 1987. (doi:10.1128/MCB.00019-09)

Hansen M, Bower C, Milne E, de Klerk N \& Kurinczuk JJ 2005 Assisted reproductive technologies and the risk of birth defects - a systematic review. Human Reproduction 20 328-338. (doi:10.1093/humrep/ deh593)

He YF, Li BZ, Li Z, Liu P, Wang Y, Tang Q, Ding J, Jia Y, Chen Z, Li L et al. 2011 Tet-mediated formation of 5-carboxylcytosine and its excision by TDG in mammalian DNA. Science 333 1303-1307. (doi:10.1126/ science.1210944)

Hendrich B, Guy J, Ramsahoye B, Wilson VA \& Bird A 2001 Closely related proteins MBD2 and MBD3 play distinctive but interacting roles in mouse development. Genes and Development 15 710-723. (doi:10.1101/ gad.194101)

Holliday R \& Pugh JE 1975 DNA modification mechanisms and gene activity during development. Science 187 226-232. (doi:10.1126/ science.187.4173.226)

Inoue A \& Zhang Y 2011 Replication-dependent loss of 5-hydroxymethylcytosine in mouse preimplantation embryos. Science 334 194. (doi:10.1126/science.1212483)

Iqbal K, Jin SG, Pfeifer GP \& Szabó PE 2011 Reprogramming of the paternal genome upon fertilization involves genome-wide oxidation of 5-methylcytosine. PNAS 108 3642-3647. (doi:10.1073/ pnas.1014033108)

Ito S, D'Alessio AC, Taranova OV, Hong K, Sowers LC \& Zhang Y 2010 Role of Tet proteins in $5 \mathrm{mC}$ to $5 \mathrm{hmC}$ conversion, ES-cell self-renewal and inner cell mass specification. Nature 466 1129-1133. (doi:10.1038/ nature09303)

Jaenisch R \& Bird A 2003 Epigenetic regulation of gene expression: how the genome integrates intrinsic and environmental signals. Nature Genetics 33 (Supplement) 245-254. (doi:10.1038/ng1089)

Kaneda M, Okano M, Hata K, Sado T, Tsujimoto N, Li E \& Sasaki H 2004 Essential role for de novo DNA methyltransferase Dnmt3a in paternal and maternal imprinting. Nature 429 900-903. (doi:10.1038/nature02633)

Kang J, Lienhard M, Pastor WA, Chawla A, Novotny M, Tsagaratou A, Lasken RS, Thompson EC, Surani MA, Koralov SB et al 2015 Simultaneous deletion of the methylcytosine oxidases Tet1 and Tet3 increases transcriptome variability in early embryogenesis. PNAS 11231 E4236-E4245. (doi:10.1073/pnas.1510510112)

Klose RJ \& Bird AP 2006 Genomic DNA methylation: the mark and its mediators. Trends in Biochemical Sciences 31 89-97. (doi:10.1016/j. tibs.2005.12.008)

Ledda S, Bogliolo L, Leoni G \& Naitana S 1999 Production and lambing rate of blastocysts derived from in vitro matured oocytes after gonadotrophin treatment of prepubertal ewes. Journal of Animal Science 77 2234-2239. (doi:10.2527/1999.7782234x)

Ledda S, Bebbere D, Ariu F, Pescatori M, Pau S, Zedda MT \& Bogliolo L 2012 Unveiling mRNA changes during meiotic progression and pre-implantation development: help from large animal models. Current Pharmaceutical Design 18 256-263. (doi:10.1016/00121606(82)90325-6)

Lee K, Hamm J, Whitworth K, Spate L, Park KW, Murphy CN \& Prather RS 2014 Dynamics of TET family expression in porcine preimplantation embryos is related to zygotic genome activation and required for the maintenance of NANOG. Developmental Biology 386 86-95. (doi:10.1016/j.ydbio.2013.11.024)

Leoni GG, Succu S, Berlinguer F, Rosati I, Bebbere D, Bogliolo L, Ledda S \& Naitana S 2006 Delay on the in vitro kinetic development of prepubertal ovine embryos. Animal Reproduction Science 92 373-383. (doi:10.1016/j.anireprosci.2005.05.027)

Leoni GG, Bebbere D, Succu S, Berlinguer F, Mossa F, Galioto M, Bogliolo L, Ledda S \& Naitana S 2007 Relations between relative mRNA abundance and developmental competence of ovine oocytes. Molecular Reproduction and Development 74 249-257. (doi:10.1002/mrd.20442) Leoni GG, Palmerini MG, Satta V, Succu S, Pasciu V, Zinellu A, Carru C, Macchiarelli G, Nottola SA \& Naitana S 2015 Differences in the kinetic 
of the first meiotic division and in active mitochondrial distribution between prepubertal and adult oocytes mirror differences in their developmental competence in a sheep model. PLOS ONE 10 e0124911. (doi:10.1371/journal.pone.0124911)

Lucifero D, La Salle S, Bourc'his D, Martel J, Bestor TH \& Trasler JM 2007 Coordinate regulation of DNA methyltransferase expression during oogenesis. BMC Developmental Biology 7 36. (doi:10.1186/1471213X-7-36)

Market-Velker BA, Zhang L, Magri LS, Bonvissuto AC \& Mann MR 2010 Dual effects of superovulation: loss of maternal and paternal imprinted methylation in a dose-dependent manner. Human Molecular Genetics 19 36-51. (doi:10.1093/hmg/ddp465)

Mayer W, Niveleau A, Walter J, Fundele R \& Haaf T 2000 Demethylation of the zygotic paternal genome. Nature 403 501-502. (doi:10.1038/35000654)

Ohki I, Shimotake N, Fujita N, Jee J, Ikegami T, Nakao M \& Shirakawa M 2001 Solution structure of the methyl-CpG binding domain of human MBD1 in complex with methylated DNA. Cell 1054 487-497. (doi:10.1016/S0092-8674(01)00324-5)

Ohsugi M, Zheng P, Baibakov B, Li L \& Dean J 2008 Maternally derived FILIA MATER complex localizes asymmetrically in cleavage-stage mouse embryos. Development 135 259-269. (doi:10.1242/dev.011445)

Okano M, Xie S \& Li E 1998 Cloning and characterization of a family of novel mammalian DNA cytosine-5 methyltransferases. Nature Genetics 19 219-220. (doi:10.1038/890)

Okano M, Bell DW, Haber DA \& Li E 1999 DNA methyltransferases Dnmt3a and Dnmt3b are essential for de novo methylation and mammalian development. Cell 99 247-257. (doi:10.1016/S00928674(00)81656-6)

Page-Lariviere F \& Sirard MA 2014 Spatiotemporal expression of DNA demethylation enzymes and histone demethylases in bovine embryos. Cellular Reprogramming 16 40-53. (doi:10.1089/cell.2013.0055)

Petrussa L, Van de Velde H \& De Rycke M 2016 Similar kinetics for 5-methylcytosine and 5-hydroxymethylcytosine during human preimplantation development in vitro. Molecular Reproduction Development 83 594-605. (doi:10.1002/mrd.22656)

Ptak G, Matsukawa K, Palmieri C, Della Salda L, Scapolo PA \& Loi P 2006 Developmental and functional evidence of nuclear immaturity in prepubertal oocytes. Human Reproduction 21 2228-2237. (doi:10.1093/ humrep/del184)

Ratnam S, Mertineit C, Ding F, Howell CY, Clarke HJ, Bestor TH, Chaillet JR \& Trasler JM 2002 Dynamics of Dnmt1 methyltransferase expression and intracellular localization during oogenesis and preimplantation development. Developmental Biology 245 304-314. (doi:10.1006/ dbio.2002.0628)

Reis Silva AR, Adenot P, Daniel N, Archilla C, Peynot N, Lucci CM, Beaujean N \& Duranthon V 2011 Dynamics of DNA methylation levels in maternal and paternal rabbit genomes after fertilization. Epigenetics $\mathbf{6}$ 987-993. (doi:10.4161/epi.6.8.16073)

Reik W 2007 Stability and flexibility of epigenetic gene regulation in mammalian development. Nature 447 425-432. (doi:10.1038/ nature05918)

Romar R, De Santis T, Papillier P, Perreau C, Thélie A, Dell'Aquila ME, Mermillod P \& Dalbiès-Tran R 2011 Expression of maternal transcripts during bovine oocyte in vitro maturation is affected by donor age. Reproduction in Domestic Animals 46 23-30. (doi:10.1111/j.14390531.2010.01617.x)

Ruddock-D'Cruz NT, Xue J, Wilson KJ, Heffernan C, Prashadkumar S, Cooney MA, Sanchez-Partida LG, French AJ \& Holland MK 2008 Dynamic changes in the localization of five members of the methyl binding domain $\mathrm{MBD}$ gene family during murine and bovine preimplantation embryo development. Molecular Reproduction and Development 75 48-59. (doi:10.1002/mrd.20712)

Russo V, Martelli A, Berardinelli P, Di Giacinto O, Bernabò N, Fantasia D, Mattioli M \& Barboni B 2007 Modifications in chromatin morphology and organization during sheep oogenesis. Microscopy Research and Technique 70 733-744. (doi:10.1002/jemt.20462)

Ruzov A, Tsenkina Y, Serio A, Dudnakova T, Fletcher J, Bai Y, Chebotareva T, Pells S, Hannoun Z, Sullivan G et al. 2011 Lineage-specific distribution of high levels of genomic 5-hydroxymethylcytosine in mammalian development. Cell Research 21 1332-1342. (doi:10.1038/cr.2011.113)
Sakashita A, Kobayashi H, Wakai T, Sotomaru Y, Hata K \& Kono T 2014 Dynamics of genomic 5-hydroxymethylcytosine during mouse oocyte growth. Genes to Cells 19 629-636. (doi:10.1111/gtc.12164)

Salvaing J, Aguirre-Lavin T, Boulesteix C, Lehmann G, Debey P \& Beaujean N 2012 5-Methylcytosine and 5-hydroxymethylcytosine spatiotemporal profiles in the mouse zygote. PLOS ONE 7 e38156. (doi:10.1371/journal.pone.0038156)

Salvaing J, Peynot N, Bedhane MN, Veniel S, Pellier E, Boulesteix C, Beaujean N, Daniel N \& Duranthon V 2016 Assessment of 'one-step' versus 'sequential' embryo culture conditions through embryonic genome methylation and hydroxymethylation changes. Human Reproduction 31 2471-2483. (doi:10.1093/humrep/dew214)

Shen L, Inoue A, He J, Liu Y, Lu F \& Zhang Y 2014 Tet3 and DNA replication mediate demethylation of both the maternal and paternal genomes in mouse zygotes. Cell Stem Cell 15 459-470. (doi:10.1016/j. stem.2014.09.002)

Smallwood SA \& Kelsey G 2012 De novo DNA methylation: a germ cell perspective. Trends in Genetics 28 33-42. (doi:10.1016/j. tig.2011.09.004)

Su YQ, Sugiura K, Woo Y, Wigglesworth K, Kamdar S, Affourtit J \& Eppig JJ 2007 Selective degradation of transcripts during meiotic maturation of mouse oocytes. Developmental Biology 302 104-117. (doi:10.1016/j. ydbio.2006.09.008)

Tervit HR, Whittingham DG \& Rowson LE 1972 Successful culture in vitro of sheep and cattle ova. Journal of Reproduction and Fertility $\mathbf{3 0}$ 493-497. (doi:10.1530/jrf.0.0300493)

Urrego R, Rodriguez-Osorio N \& Niemann H 2014 Epigenetic disorders and altered gene expression after use of Assisted Reproductive Technologies in domestic cattle. Epigenetics 9 803-815. (doi:10.4161/ epi.28711)

Valinluck V, Tsai HH, Rogstad DK, Burdzy A, Bird A \& Sowers LC 2004 Oxidative damage to methyl-CpG sequences inhibits the binding of the methyl-CpG binding domain MBD of methyl-CpG binding protein 2 MeCP2. Nucleic Acids Research 32 4100-4108. (doi:10.1093/nar/ gkh739)

Wade PA 2001 Methyl CpG binding proteins: coupling chromatin architecture to gene regulation. Oncogene 20 3166-3173. (doi:10.1038/ sj.onc.1204340)

Walker SK, Hill JL, Kleemann DO \& Nancarrow CD 1996 Development of ovine embryos in synthetic oviductal fluid containing amino acids at oviductal fluid concentrations. Biology of Reproduction 55 703-708. (doi:10.1095/biolreprod55.3.703)

Wang L, Zhang J, Duan J, Gao X, Zhu W, Lu X, Yang L, Li G, Ci W, Li W et al. 2014 Programming and inheritance of parental DNA methylomes in mammals. Cell 157 979-991. (doi:10.1016/j.cell.2014.04.017)

Wossidlo M, Nakamura T, Lepikhov K, Marques CJ, Zakhartchenko V, Boiani M, Arand J, Nakano T, Reik W \& Walter J 2011 5 -Hydroxymethylcytosine in the mammalian zygote is linked with epigenetic reprogramming. Nature Communications 2241. (doi:10.1038/ncomms1240)

Wu H \& Zhang Y 2011 Mechanisms and functions of Tet protein-mediated 5-methylcytosine oxidation. Genes and Development 25 2436-2452. (doi:10.1101/gad.179184.111)

Yamaguchi S, Hong K, Liu R, Inoue A, Shen L, Zhang K \& Zhang Y 2013 Dynamics of 5-methylcytosine and 5-hydroxymethylcytosine during germ cell reprogramming. Cell Research 23 329-339. (doi:10.1038/ cr.2013.22)

Young LE \& Beaujean N 2004 DNA methylation in the preimplantation embryo: the differing stories of the mouse and sheep. Animal Reproduction Science 82-83 61-78. (doi:10.1016/j.anireprosci.2004.05.020)

Young LE, Sinclair KD \& Wilmut I 1998 Large offspring syndrome in cattle and sheep. Reviews of Reproduction 33 155-163. (doi:10.1530/ ror.0.0030155)

Received 28 November 2016

First decision 22 December 2016

Revised manuscript received 10 February 2017

Accepted 28 February 2017 